\title{
Analisis Performansi Algoritma Routing First Contact dengan Stationary Relay Node pada Delay Tolerant Network
}

\author{
LEANNA VIDYA YOVITA, JODI NUGROHO RESTU
}

\author{
Program Studi S1 Teknik Telekomunikasi Fakultas Teknik Elektro \\ Email:leanna@telkomuniversity.ac.id
}

\begin{abstract}
ABSTRAK
Algoritma routing pada jaringan klasik dapat berjalan jika hubungan end-to-end selalu ada. Algoritma routing ini bekerja dengan menggunakan informasi mengenai seluruh jalur yang tersedia. Untuk itu, pada jaringan dengan kondisi ekstrim seperti ini diperlukan algoritma routing yang sesuai. Salah satu algoritma routing yang dapat dijalankan pada Delay Tolerant Network (DTN) adalah First Contact. Algoritma ini akan melakukan penggandaan pesan yang dibawanya untuk kemudian diberikan kepada node lainnya yang pertama kali ditemui. Dalam penelitian ini ditambahkan stationary relay node untuk meningkatkan delivery probability. Dengan penambahan stationary relay node diperoleh peningkatan delivery probability 2 hingga 6\% dibandingkan dengan jaringan tanpa stationary relay node. Parameter overhead ratio meningkat sebesar $7-18 \%$ dibandingkan jaringan tanpa Stationary relay node. Algoritma First Contact dengan tambahan Stationary relay node juga memberikan tambahan average latency, 118 - 171 detik. Nilai ini berbanding lurus dengan jumlah mobile node DTN yang ada pada area tersebut.
\end{abstract}

Kata kunci: Delay Tolerant Network, first contact, Stationary relay node, routing algorithm, delivery probability, overhead ratio, average latency.

\begin{abstract}
Classical routing algorithms only works if there is end to end connection. This algorithms uses the information about every available path, and then choose the best path related to spesific metric.. For the networks with the extreme condition, it is needed the suitable routing alorithms. One of the routing algorithms that is able to be applicated in Delay Tolerant Network (DTN) is First Contact. This algorithm will make a single copy message and then forward it to the first encountered node. In this research, the stationaryrelaynodes were added to improve delivery probability. The effect of adding stationary relay node is increasing the delivery probability about 2-6\%, compared to networks without stationary relay node. The overhead ratio increased about $7-18 \%$ compared to networks without stationary relay node. First Contact algorithm with stationary relay node gives bigger average latency, $118-171$ second. This value is directly proportional to the number of mobile DTN nodes that exist in the area.
\end{abstract}

Keywords: Delay Tolerant Network, first contact, Stationary relay node, routing algorithm, delivery probability, overhead ratio, average latency.. 


\section{PENDAHULUAN}

Algoritma routing pada jaringan klasik dapat berjalan bila hubungan end to end selalu ada. Algoritma ini bekerja dengan cara mengumpulkan informasi mengenai semua jalur yang tersedia, dan kemudian memilih jalur terbaik dari seluruh pilihan jalur yang sudah ada tersebut. Pada jaringan wireless, hubungan end-to-end ini tidak selalu ada.Untuk jaringan dengan kondisi ekstrim dimana hubungan end-to-end tidak selalu ada, algoritma routing klasik tidak dapat berjalan dengan baik.Diperlukan algoritma lainnya yang dapat mengakomodasi kondisi tersebut.

\subsection{Delay Tolerant Network (DTN)}

Delay Tolerant Network merupakan jaringan dimana hubungan end-to-enctidak selalu tersedia (Keranen, 2008). Pada mulanya konsep DTN ini dikembangkan oleh NASA untuk komunikasi antar planet, dikenal dengan nama InterPlanetary Communication (IPN) (Ioanis,dkk, 2009). Namun, konsep DTN dapat dikembangkan untuk komunikasi teresrial lainnya dan dapat dimanfaatkan untuk berbagai kondisi jaringan yang ekstrim, dimana delay pengiriman paket dapat saja sangat besar dan tidak ada infrastruktur yang tetap pada jaringan, misalkan pada daerah terpencil yang tidak memiliki infrastruktur jaringan. Pada kondisi ini, data dapat dibawa oleh node DTN yang bergerak, untuk kemudian diteruskan ke node DTN lain yang ditemuinya.

Pada DTN, pesan akan diteruskan ke node yang lainnya sampai ke tujuan dengan menggunakan konsep routing yang berbeda dengan routing klasik. Karena hubungan endto-end yang tidak selalu ada ini, algoritma routing tidak akan menggunakan konsep lama dimana informasi mengenai seluruh path yang tersedia, akan dikumpulkan terlebih dahulu sebelum memutuskan jalur terbaik yang akan digunakan untuk mengirimkan pesan. Akan tetapi, nodeakan memutuskan untuk meneruskan atau tidak meneruskan paket ke node lainnya berdasarkan karakteristik algoritma routing itu sendiri.

DTN memiliki layer tambahan, yaitu bundle layer.Layer ini terletak di atas layer transport pada internet layer. Bundle layer memungkinkan pesan untuk disimpan dalam node DTN dan dibawa oleh node, dan kemudian diteruskan jika bertemu dengan node lainnya. Pada jaringan internet, hal ini tidak dapat dilakukan. Pada DTN dilakukan konsep store, carry, and forward.

\begin{tabular}{|c|}
\hline Aplikasi \\
\hline Bundle \\
\hline Transport \\
\hline Network \\
\hline Datalink \\
\hline Fisik \\
\hline
\end{tabular}

Layer pada DTN

\begin{tabular}{|c|}
\hline Aplikasi \\
\hline \\
\hline Transport \\
\hline Network \\
\hline Datalink \\
\hline Fisik \\
\hline
\end{tabular}

Layer internet

Gambar 1. Layer pada DTN dan internet (Warthman, 2003) 

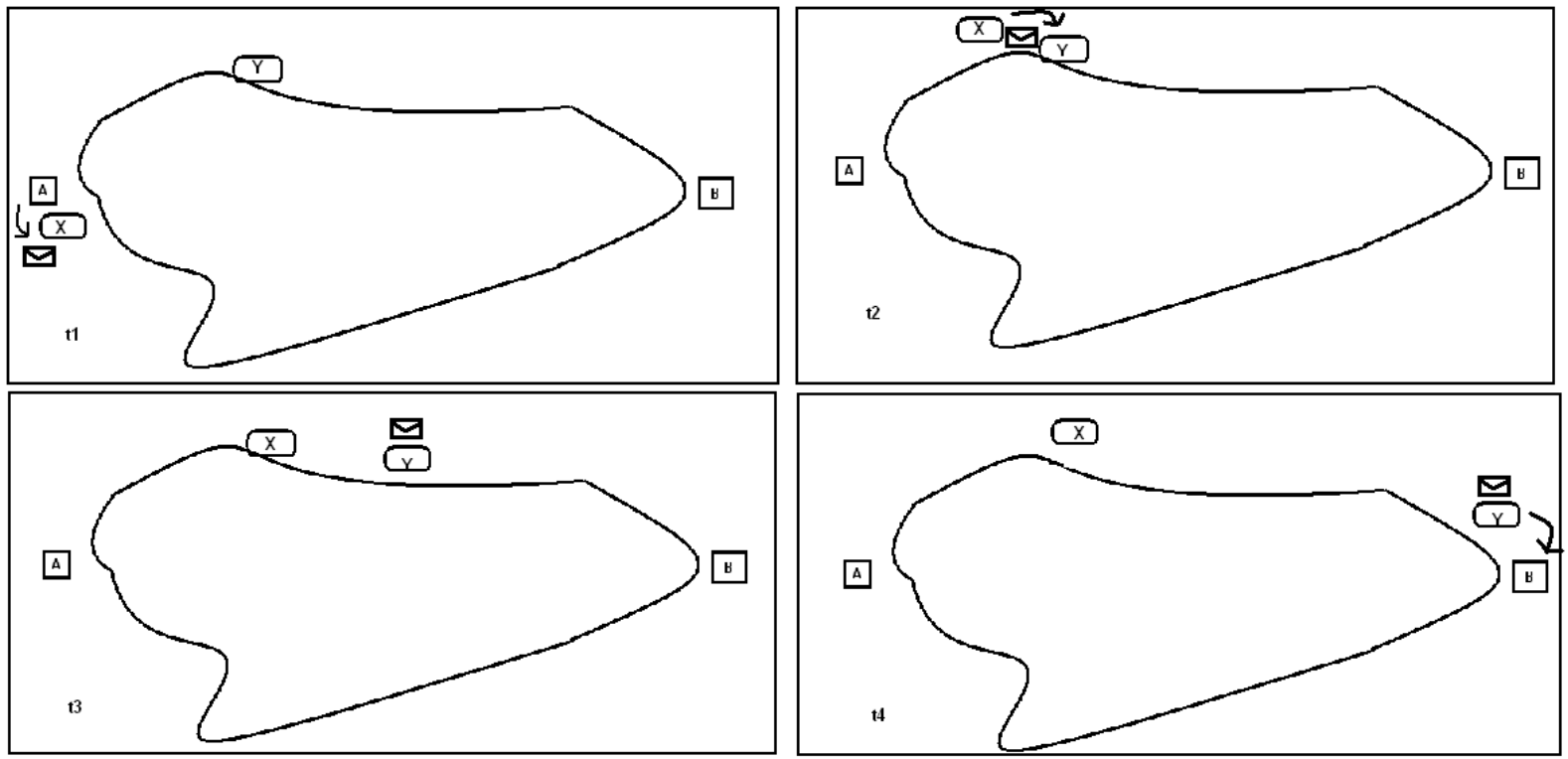

Gambar 2. Ilustrasi jaringan DTN

Pada ilustrasi di Gambar 2 terlihat bahwa node A dan B adalah node statis dan node X serta $\mathrm{Y}$ merupakan node yang bergerak. Misalkan tidak ada jaringan yang menghubungkan node $\mathrm{A}$ dan $\mathrm{B}$, namun nodeA membutuhkan untuk mengirim data ke node $\mathrm{B}$. Pada jaringan klasik, hal ini tidak mungkin dilakukan. Pada DTN, pesan dari node A dapat ditumpangkan kenode $\mathrm{X}$ yang berjalan melewati node $\mathrm{A}$. Dalam perjalanannya, node $\mathrm{X}$ bertemu dengan node $\mathrm{Y}$. Karena node $\mathrm{X}$ tidak akan berjalan melewati node $\mathrm{B}$, maka node $\mathrm{X}$ menumpangkan pesannya ke node $\mathrm{Y}$ untuk dibawa. Pada $\mathrm{t} 3$, node $\mathrm{Y}$ bergerak menuju node statis $\mathrm{B}$. Dan pada saat node $\mathrm{Y}$ melewati node $\mathrm{B}$, pesan itu dapat disampaikan. Dengan skema ini, paket dari $\mathrm{A}$ akan dapat sampai ke $B$, walaupun waktu yang dibutuhkan untuk pengiriman mungkin saja besar. Pada jaringan klasik, jika delay terlalu besar, paket akandi buang dari jaringan.

\subsection{Algoritma Routing First Contact}

Algoritma routingFirst Contact merupakan algoritma routing yang paling sederhana, sehingga setiap node DTN yang menggunakan algoritma ini tidak harus dibekali kemampuan komputasi yang tinggi. Namun demikian, algoritma First Contact memberikan delivery probabilityyang lebih tinggi dibandingkan dengan Direct Delivery (Mangrulkar, 2012).

Pada algoritma First Contact, setiap node akan menggandakan (single copy) dan meneruskan pesan yang ada padanya ke node lain yang pertama kali ditemui (Mangrulkar, 2012). Hal ini menyebabkan kemungkinan pesan sampai ke tujuan menjadi lebih tinggi, karena makin banyak node yang membawa salinan pesan tersebut. Proses ini diilustrasikan pada Gambar 3. Misalkan nodeA membawa pesan pada waktu ke t1. Pada waktu ke -t2, node A bertemu dengan node $\mathrm{C}$. Node A akan memberikan salinan pesan ke node $\mathrm{C}$, sementara pesan yang asli masih dibawa oleh node $\mathrm{A}$. Pada waktu ke-t3, node $\mathrm{C}$ bertemu dengan node $\mathrm{D}$ sebagai node tujuan pengiriman pesan. Node $\mathrm{C}$ akan mengirimkannya kepada node D. 


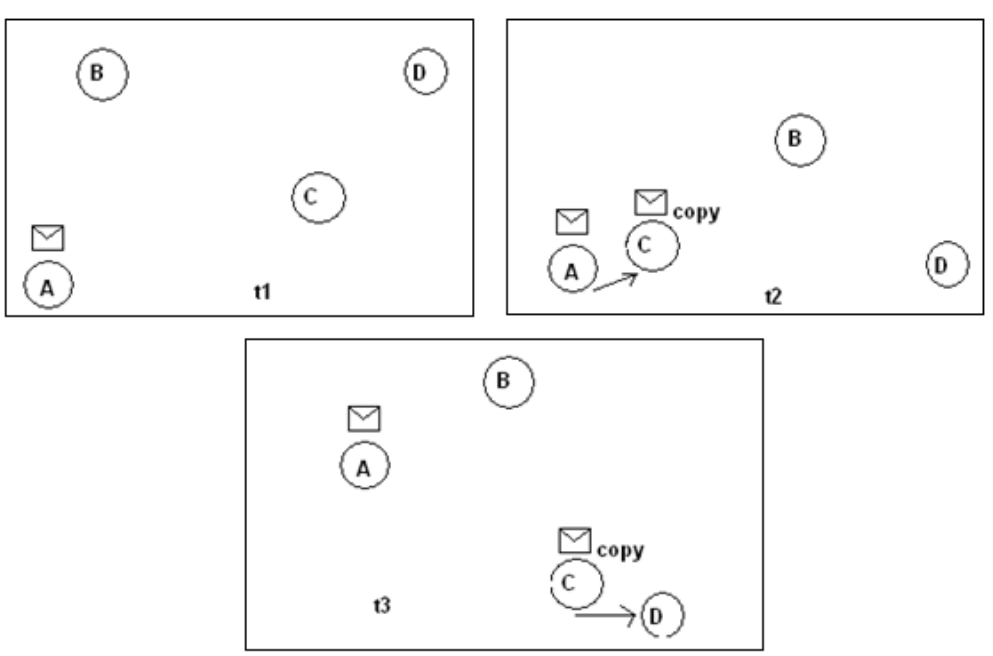

\section{Gambar 3. Proses pengiriman paket dari node A ke D menggunakan First Contact}

\subsection{Parameter Evaluasi}

Pada penelitian ini dianalisis beberapa parameter performansi, yaitu delivery probability, overhead ratio dan average latency. Delivery probability menunjukkan prosentase terkirimnya pesan sampai ke tujuan. Nilai parameter diperoleh dari perbandingan antar paket yang berhasil sampai di penerima dengan paket yang diproduksi oleh node. Overhead ratio menunjukkan jumlah seluruh paket yang merupakan salinan dari paket asli dibandingkan dengan jumlah paket asli yang diproduksi. Parameter average latency menunjukkan delay rata-rata dalam pengiriman paket dari sumber ke tujuan.

\section{METODOLOGI PENELITIAN}

Pada penelitian yang telah dilakukan sebelumnya, sudah dianalisis perbandingan performansi antara algoritma Direct Delivery, First Contact, Epidemic dan MaxProp dengan berbagai ukuran buffer (Mangrulkar, 2012). Kemudian telah dianalisis pula perbandingan performansi antara Direct Delivery dan First Contact dengan berbagai kondisi kepadatandan kecepatan node (Restu, J., N., dkk, 2015). Pada penelitian ini dilakukan analisis performansi First Contact dengan menambahkan stationary relay node pada area penelitian dan melihat dampaknya berdasarkan jarak dan letak stationary relay node. stationary relay node bertindak sebagai noderelay yang memiliki kemampuan untuk meneruskan pengiriman paket ke node lainnya. Stationary node akan meningkatkan jaminan bahwa sebuah node akan bertemu dengan node lainnya sebagai relay atau media transfer berikutnya menuju ke tujuan.

Metode penelitian dibagi menjadi beberapa tahap untuk mencapai tujuan penelitian, yaitu:

1. Identifikasi masalah

Pada tahap ini dilakukan identifikasi masalah, dengan membaca literature dan paper penelitian terkait yang sudah dilakukan sebelumnya. Berdasarkan hasil dari proses ini diperoleh bahwa DTN memerlukan skema routing yang sangat berbeda dengan jaringan klasik. Dari banyak algoritma routing untuk DTN yang telah diteliti sebelumnya, First Contact memiliki keunggulan dari sisi kesederhanaannya. Namun, perlu diteliti lebih lanjut modifikasi baik dari sisi internal algoritma maupun dari 
modifikasi infrastruktur jaringannya untuk meningkatkan performansi algoritma ini.Pada penelitian ini dimaksudkan untuk meneliti modifikasi yang dapat dilakukan dari sisi infrastruktur jaringan untuk meningkatkan performansi algoritma First Contact.

2. Desain model

Berdasarkan hasil identifikasi masalah dari tahap 1, dilakukan desain model penelitian untuk memecahkan masalah. Adapun model penelitian ini adalah sesuai gambar 4 .

Jaringan ekstrim seperti DTN membutuhkan algoritma routing yang berbeda dari routing pada jaringan klasik.
Algoritma routing First Contact dapat digunakan pada jaringan DTN, dengan keunggulan dari sisi kesederhanaan aplikasinya, namun perlu diteliti lebih lanjut untuk meningkatkan delivery probabilitynya
Dilakukan penelitian untuk

meningkatkan delivery probability

pada jaringan dengan First Contact

dan menguji performansinya.

\section{Gambar 4. Model Penelitian}

3. Desain pemecahan masalah dan evaluasi

Untuk meningkatkan performansi First Contact, dilakukan pemodelan jaringan dengan menambahkan stationary relay node. Pemodelan dilakukan dengan area simulasi jalan tol, mulai dari gerbang tol Buah Batu sampai ke gerbang tol Cileunyi. Kemudian dilakukan pengubahan jarak letak stationary relay node dan menganalisis pengaruhnya terhadap performansi jaringan secara keseluruhan. Performansi jaringan akan dianalisis berdasarkan parameter delivery probability, overhead ratio dan average latency.

\section{Pengumpulan data}

Data diperoleh dari hasil simulasi menggunakan tools simulasi DTN, yaitu ONEsim 1.5.0 RC2.Nodeakan dimodelkan untuk bergerak berdasarkan jalur tertentu pada peta. Peta yang digunakan adalah peta ruas jalan tol mulai dari Gerbang Tol Buah Batu sampai gerbang Tol Cileunyi. Mobile node DTN diatur untuk bergerak mengikuti ruas jalan tersebut.Untuk mengintegrasikan peta ke dalam simulator digunakan Open Street Map dan OpenJUMP 1.8.0. Data yang diperoleh dari simulasi tersebut kemudian akan dianalisis berdasarkan parameter delivery probability, overhead ratio, dan average latency.

\section{Penarikan kesimpulan}

Berdasarkan evaluasi data yang tersedia, akan ditarik kesimpulan terkait dengan performansi First Contact berdasarkan berbagai kondisi pengujian. 


\section{HASIL DAN DISKUSI}

Pada penelitian ini ditentukan terlebih dahulu parameter inisialisasi yang digunakan, dapat dilihat pada Tabel 1.

Tabel 1. Parameter Simulasi

\begin{tabular}{|l|c|}
\hline \multicolumn{1}{|c|}{ Parameter } & Skenario \\
\hline Lokasi Penelitian & Ruas Tol Buahbatu-Cileunyi \\
\hline Panjang Rute & 5 dan 25 node \\
\hline Kepadatan kendaraan & $140 \mathrm{Km}$ \\
\hline Jarak Stationarynode & $500 \mathrm{~KB}$ \\
\hline Ukuran Buffer & $19.44-23.6 \mathrm{~m} / \mathrm{s}$ \\
\hline Ukuran Paket & 3600 detik \\
\hline Kecepatan kendaraan & $1.125 \mathrm{MBps}$ \\
\hline Waktu Simulasi & Wifi $802.11 \mathrm{p}$ \\
\hline Kecepatan pengiriman data & Omnidirectional \\
\hline Antarmuka & $300 \mathrm{~m}$ \\
\hline Pola pancar & First Contact \\
\hline Cakupan area & $10-20$ detik \\
\hline Protokol Routing & Map based movement, Stationary movement \\
\hline Interval Bundle & \\
\hline Model Mobilitas & \\
\hline
\end{tabular}

Pengujian dilakukan dengan beberapa skenario dengan parameter umum sesuai Tabel 1 , dan tambahan kondisi pengujian berdasarkan skenario 1 sampai 4 sesuai dengan Tabel 2 .

Tabel 2. Skenario simulasi

\begin{tabular}{|c|c|c|}
\hline No & Skenario & Penjelasan \\
\hline 1 & Skenario 1 & Disimulasikan jaringan tanpa stationary relay node \\
\hline 2 & Skenario 2 & $\begin{array}{r}\text { Disimulasikan jaringan dengan stationary relay node } \\
\text { dengan jarak tiap stationarynode= 5 km }\end{array}$ \\
\hline 3 & Skenario 3 & $\begin{array}{r}\text { Disimulasikan jaringan dengan stationarynode dengan } \\
\text { jarak tiap stationarynode }=6 \mathrm{~km}\end{array}$ \\
\hline 4 & Skenario 4 & $\begin{array}{c}\text { Disimulasikan jaringan dengan stationarynode dengan } \\
\text { jarak tiap stationarynode }=7 \mathrm{~km}\end{array}$ \\
\hline
\end{tabular}




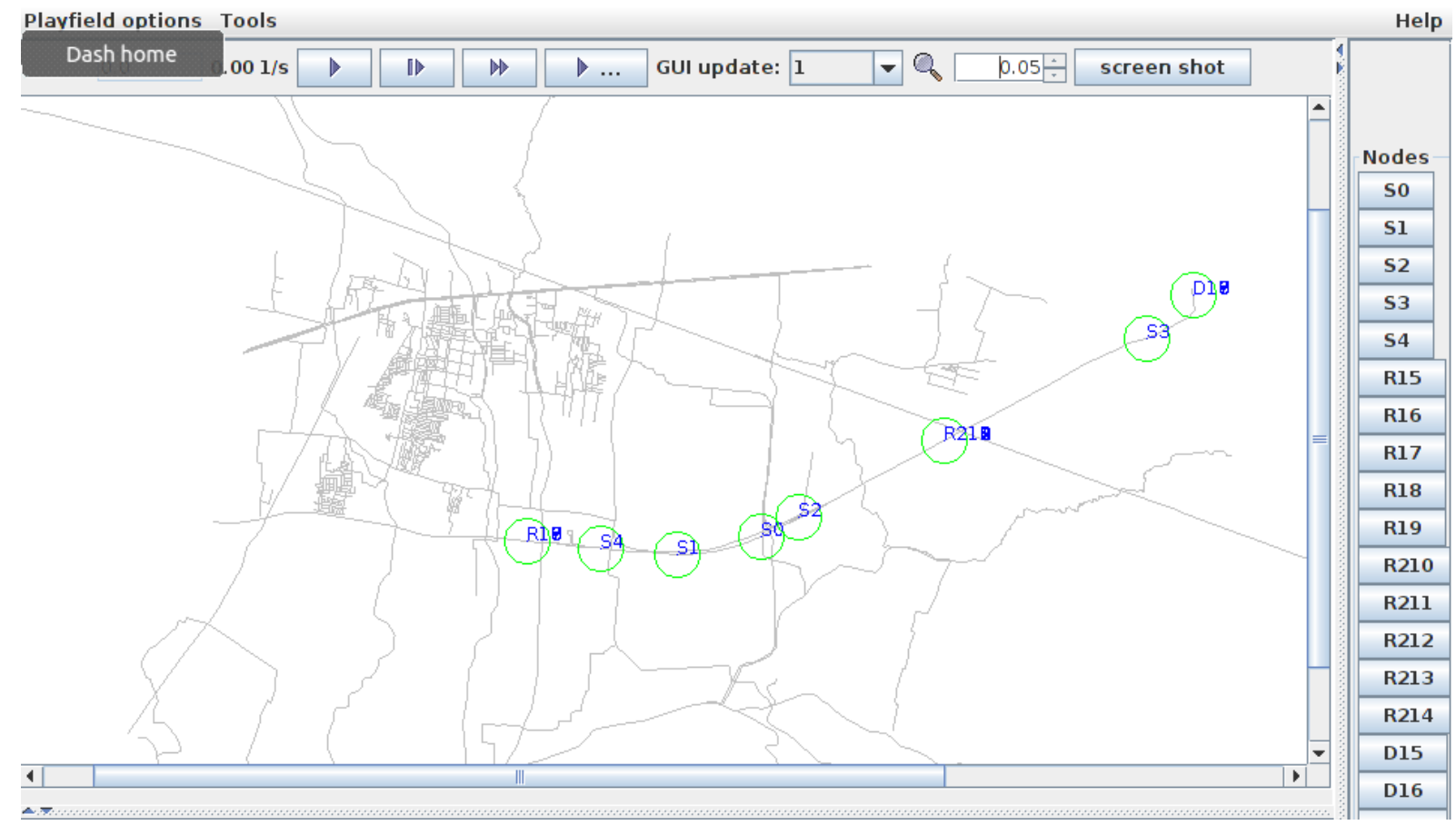

Gambar 5. Jalur pergerakan node

Gambar 5 menunjukkan peta yang digunakan dalam simulasi. Mobile node akan bergerak mengikuti jalur jalan tol pada peta, sedangkan stationary relay node diletakkan statis di ruas jalan sesuai dengan skenario jarak peletakan. Mobile node akan bergerak dari gerbang Buah Batu menuju ke gerbang Cileunyi. Bentuk lingkaran pada gambar menunjukkan node beserta area cakupan sinyalnya.

\subsection{Hasil pengujian}

Pada simulasi digunakan jalur peta mulai dari gerbang tol Buah Batu sampai gerbang tol Cileunyi dengan panjang jalur total $14,140 \mathrm{~km}$. Di sepanjang jalur ini node akan bergerak. Simulasi dilakukan dengan menjalankan First Contact sebagai algoritma routing bagi node node DTN tersebut dan mengatur kondisi sesuai parameter umum dan skenario pengujian pada Tabel 1 dan Tabel 2. Hasil performansinya dijelaskan berikut ini.

\subsubsection{Delivery probability}

Delivery probability menunjukkan probabilitas pesan sampai ke tujuan. Parameter ini diperoleh dari formula :

$$
\text { Delivery probability }=\frac{\text { Jumlah pesan yang sukses diterima oleh node tujuan }}{\text { Jumlah pesan yang diproduksi }}
$$

Dari hasil simulasi terlihat bahwa terdapat peningkatan delivery probability saat ditambahkan stationary relay node. Perubahan jumlah mobile nodeDTN yang ada pada area tersebut juga mempengaruhi delivery probability. 
Yovita, L., V., Restu, J., N.

Tabel 3. Delivery probability

\begin{tabular}{|l|c|c|}
\hline \multicolumn{1}{|c|}{ Keterangan } & 5 Node & 25 Node \\
\hline Jarak SN 5 km & 0,276 & 0,341 \\
\hline Jarak SN 6 km & 0,2601 & 0,335 \\
\hline Jarak SN 7 km & 0,2469 & 0,3224 \\
\hline Without Stationary Node & 0,229 & 0,28 \\
\hline
\end{tabular}

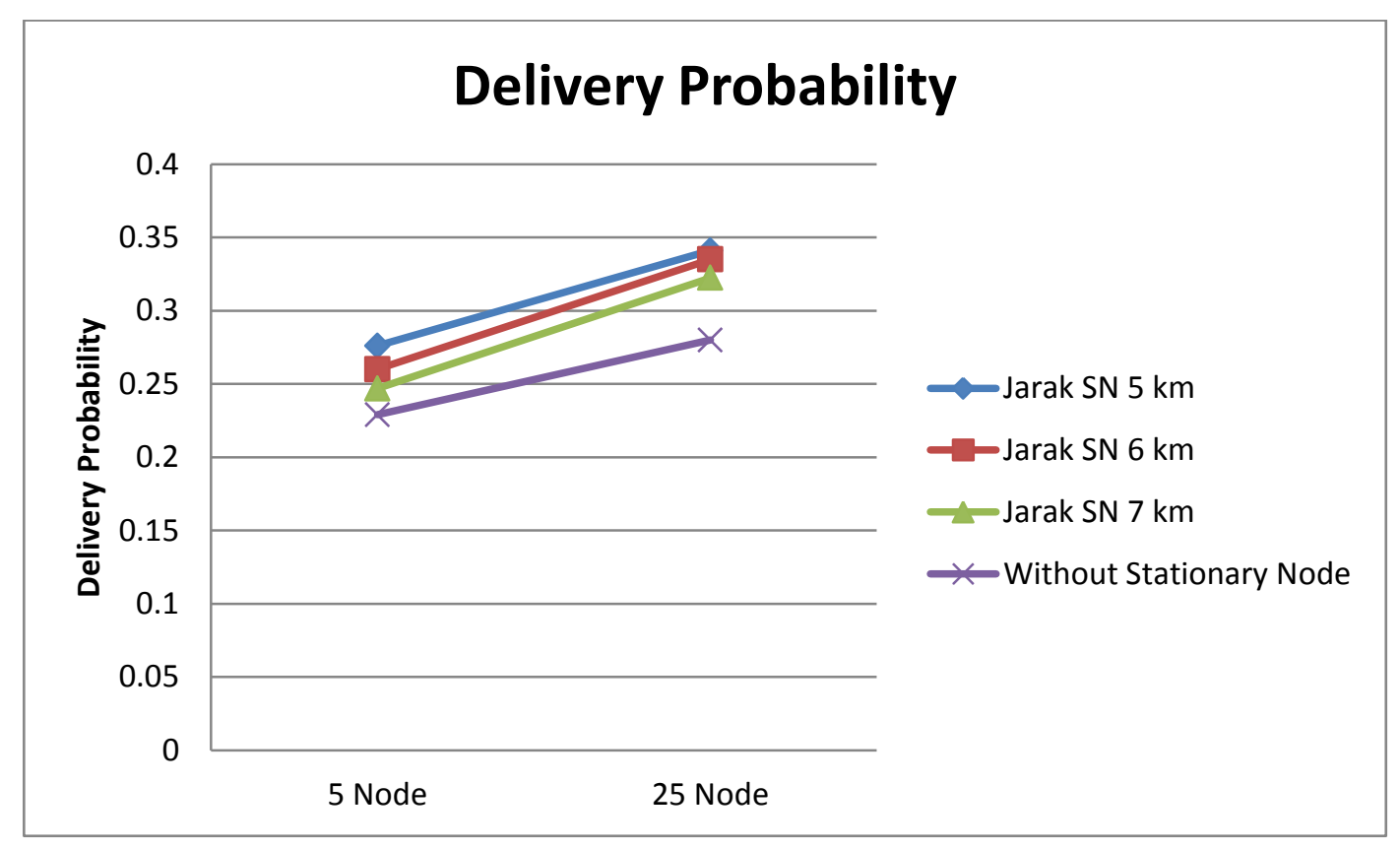

Gambar 6. Grafik Delivery probability

Dari grafik pada Gambar 6 terlihat bahwa pertambahan jumlah node DTN dalam area meningkatkan nilai delivery probability. Jumlah node yang lebih banyak menyebabkan pesan dapat diantarkan melalui lebih banyak pilihan jalur sehingga delivery probability meningkat2$6 \%$ daripada tanpa stationary relay node. Jaringan dengan tambahan stationary relay nodeakan meningkatkan pula nilaidelivery probability. Ketika node DTN mobile bertemu dengan stationary relay node pada jalur yang dilaluinya sebagai node pertama, maka node tersebut akan mengirimkan pesannya ke stationary relay node. Hal ini menyebabkanDTN mobilenode memperoleh kepastian bahwa selalu ada noderelay yang bisa dimanfaatkan sebagai perantara menuju ke destinasi.

\subsubsection{Overhead ratio}

Overhead ratio merupakan parameter performansi yang perlu dianalisis terkait dengan penambahan beban jaringan. Pada penambahan stationary relay node, overhead ratioakan meningkat pula $7-18 \%$ karena ada tambahan node yang mungkin oleh mobile node DTN dan berakibat ada tambahan salinan pesan yang akan dibuat oleh node dalam jaringan tersebut. 
Tabel 4. Overhead ratio (\%)

\begin{tabular}{|l|c|c|}
\hline \multicolumn{1}{|c|}{ Keterangan } & 5 Node & 25 Node \\
\hline Jarak SN 5 km & 20,4587 & 50,6475 \\
\hline Jarak SN 6 km & 25,3293 & 46,0226 \\
\hline Jarak SN 7 km & 15,5612 & 45,2891 \\
\hline Without StationaryNode & 7,6813 & 36,9699 \\
\hline
\end{tabular}

Perubahan jumlah mobilenode DTN juga mempengaruhi parameter ini. Hal ini disebabkan karena jumlah hop yang dilalui oleh pesan sampai ke node tujuan akan bertambah. Jumlah salinan pesan yang beredar di jaringan juga akan makin banyak. Pertambahan jumlah mobile node dari 5 node menjadi 25 node meningkatkan overhead ratio 20 - 30\%, seperti diperlihatkan oleh grafik pada Gambar 7.

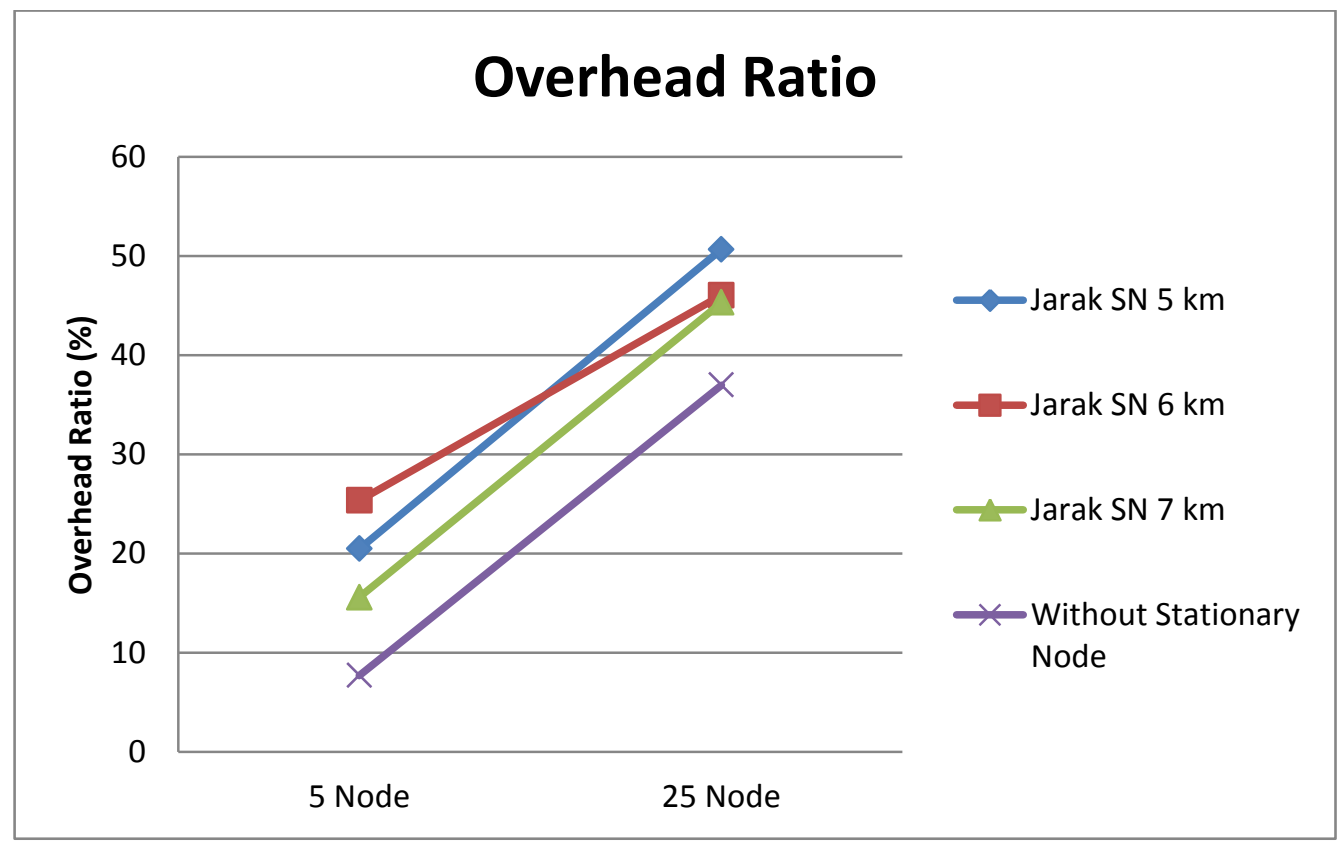

Gambar 7. Grafik Overhead ratio

\subsubsection{Average latency}

Average latency dihitung mulai dari paket dikirim sampai paket tersebut diterima oleh node tujuan. Average latency meningkat sebanding dengan jumlah mobile node DTN, disebabkan karena semakin banyak node akan makin banyak menyumbang delay proses di dalam node itu sendiri. Delay juga meningkat jika dibandingkan antara jaringan tanpa stationary relay node dengan jaringan yang diberi stationary relay node, sebagai akibat bahwa stationary relay nodeakan menyumbangkan delay proses juga sebelum meneruskan paket ke node lainnya yang dikenali pertama kali. 
Yovita, L., V., Restu, J., N.

Tabel 5.Average latency

\begin{tabular}{|l|c|c|}
\hline Keterangan & 5 Node & 25 Node \\
\hline Jarak SN 5 km & 439,6927 & 489,2328 \\
\hline Jarak SN 6 km & 435,2366 & 480,4532 \\
\hline Jarak SN 7 km & 387,3051 & 471,3216 \\
\hline Without Stationary Node & 268,5549 & 456,8796 \\
\hline
\end{tabular}

Pada jumlah mobile node yang kecil (5 node), kenaikan average latency cukup jika dibandingkan antara jaringan tanpa stationary relay node dengan jaringan yang memiliki stationary relay node, yaitu 118 detik - 171 detik. Dengan naiknya jumlah mobilenode menjadi 25 node, average latency naik dalam jumlah yang lebih kecil, yaitu 14 detik - 32 detik, jika dibandingkan antara jaringan tanpa stationary relay node dengan jaringan yang memiliki stationary relay node. Kondisi ini dapat dilihat pada Gambar 8.

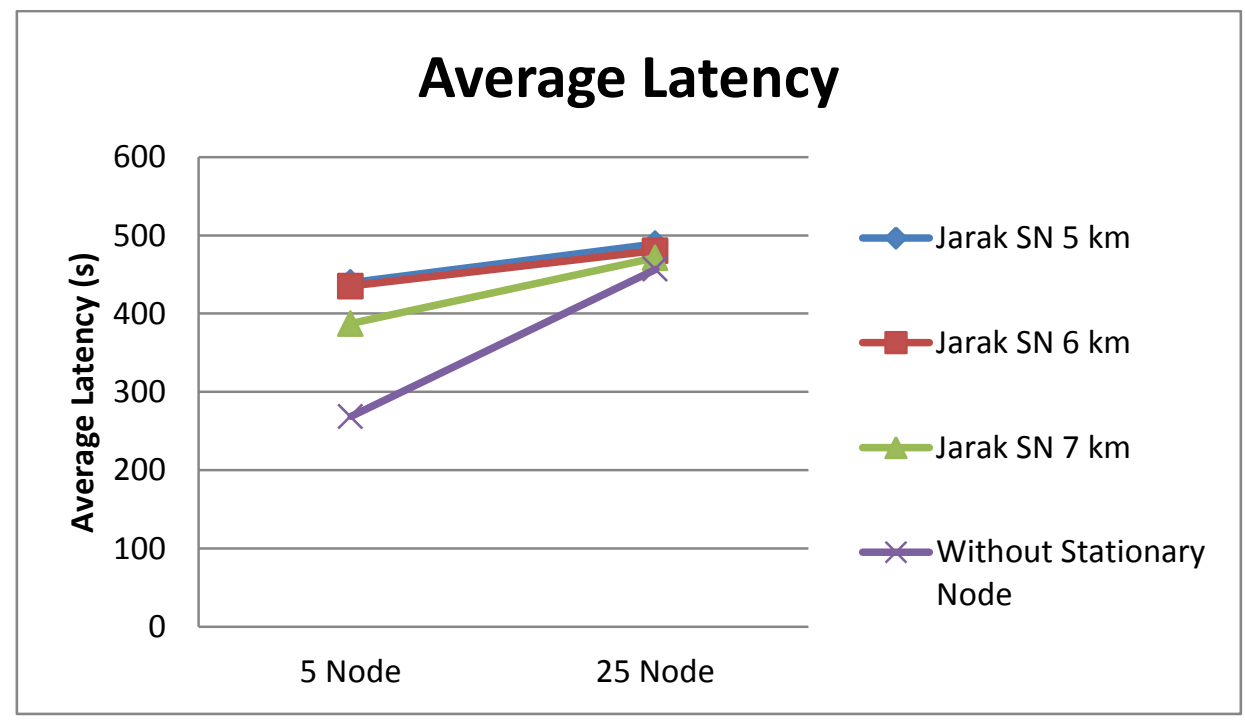

Gambar 8. Grafik Average latency

\section{KESIMPULAN}

Berdasarkan penelitian yang telah dilakukan dapat disimpulkan bahwa:

1. Algoritma First Contact dengan tambahan stationary relay nodeakan meningkatkan probability delivery 2-6\%.

2. Algoritma First Contact dengan tambahan stationary relay node memberikan peningkatan pula terhadap beban jaringan dimana nilai overhead ratiomeningkat sebesar $7-18 \%$ dibandingkan jaringan tanpa stationary relay node.

3. Algoritma First Contact dengan tambahan stationary relay nodememberikan tambahan average latency 118 - 171 detik. Average nilai ini berbanding lurus dengan jumlah mobilenode DTN yang ada pada area tersebut. 


\section{DAFTAR RUJUKAN}

Keranen, A. (2008). Special Assignment : Opportunistic Network Environment Simulator. Finlandia : Helsinki University of Technology.

Psaras, I., Wood, L., Taffazolli, L. (2009). Delay Disruption Tolerant Networking State of the art and Future Challenges. Center of Communication Systems Research (CCSR) Elsifier.

Warthman, F. (2003). Delay Tolerant Networks (DTNs) : A Tutorial Based on DTN Architecture DTN Research Group Internet Draft. USA : Warthman Associates.

Mangrulkar, R., S., Atique, M. (2012). Performance Evaluation of Delay Tolerant Routing Protocol by Variation in Buffer Size. IEEE Conf. Publication (pp. 674-678).

Restu, J., N., Yovita, L., V., Doan P. (2015). Analisis Performansi Vehicular Ad Hoc Network Menggunakan Protokol Routing DTN Direct Delivery dan First Contact. Seminar Nasional Universitas PGRI Yogyakarta.

Rodrigues, J.,J.,P.,C. (2014). Advanced in Delay-tolerant Networks(DTNs) $1^{\text {st }}$ Edition. Woodhead Publishing.

Doering, M., Pögel, T., and Wolf, L. (2010). DTN Routing in Urban Public Transport Systems Categories and Subject Descriptors (pp. 55-62). 